\title{
Sensory and physico-chemical characteristics of desserts prepared with egg products processed by freeze and spray drying
}

\author{
Marcelo Nunes de JESÚS ${ }^{1}$, Ana Beatriz ZANQUI ${ }^{2}$, Patrícia VALDERRAMA ${ }^{1}$, Augusto TANAMATI ${ }^{1}$, \\ Swami Arêa MARUYAMA², Nilson Evelázio de SOUZA, Makoto MATSUSHITA ${ }^{2 *}$
}

\begin{abstract}
In this work, three freeze-dried (FD) egg products (whole egg (WE), egg yolk (EY) and egg white (EW)) were obtained and the acceptability of confections prepared with each was evaluated. Sensory analyses for confections were performed by hedonic testing with fifty panelists in each evaluation. The studied confections were: Condensed Milk Pudding (P), Quindim (Q) and Meringue (M). The results obtained for confections made with FD egg products were compared with the achieved through other formulations of the same desserts made with fresh (F) or spray-dried (SD) egg products. The sensory analysis results for confections made with FD egg products showed good acceptance by panelists. A principal component analysis of the sensory evaluation data was carried out to identify similarities between the different egg products. The PCA supported the conclusion that FD egg products can substitute their fresh and SD counterparts in dessert formulations with good acceptability while keeping the advantages conferred by the freeze-drying method.
\end{abstract}

Keywords: principal component analysis; freeze-dried eggs; confections; sensory analysis; egg products.

\section{Introduction}

Chicken egg and its derivatives (whole egg (WE), egg yolk (EY) and egg white (EW)) have well-known properties (POWRIE; NAKAIM, 1986; AMERICAN..., 2012). It is a complete food source with components essential to human nutrition, like high quality proteins, $\omega-3$ fatty acids, vitamins, carotenoids and minerals (MANN et al., 2008; MINE, 1995; UNITED..., 2012; WENZEL; SEUSS-BAUM; SCHLICH, 2010, 2011; KOVACS-NOLAN; PHILLIPS; MINE, 2005; AMERICAN..., 2012; SIMOPOULOS, 2011; KING, 2009). Its cholesterol content, about $213 \mathrm{mg}$ per egg (SILVA et al., 2008), is a point of discussion among researchers, but recent papers do not attribute elevations in cholesterol levels in its consumers as due solely to ingestion of products made with eggs (SPENCE; JENKINS; DAVINGNON, 2010). Industrially, dehydrated eggs have many advantages over fresh ones, like inhibition of pathogenic microorganism development, elimination of refrigeration needed in the storage of egg products, easier handling and, most important, a significant extension in their shelf life, increasing from a few weeks to twelve months (POWRIE; NAKAIM, 1986; JONES, 2007). The usual method to dehydrate eggs is spray-drying (SD), because it combines low cost and high production. However, this treatment is based on passing a water steam through the sample at high temperature (between $145-195{ }^{\circ} \mathrm{C}$ ) to carry away the water content (KOÇ et al., 2011a,b). This range of temperatures can interfere with the organoleptic attributes of egg samples and induce physicochemical changes such as formation of foam, emulsification and gelification (AYADI et al., 2008; CABONI et al., 2005; ROSSI et al., 2010). In addition to these factors, heat treatment deteriorates proteins, carotenoids
(VAN DER PLANCKEN; VAN LOEY; HENDRICKX, 2006), polyunsaturated fatty acids (GALOBART et al., 2001; VERARDO et al., 2010) and other important compounds present in eggs (GUILMINEAU; KULOZIK, 2007; COIMBRA et al., 2006; JAEKEL; DAUTEL; TERNES, 2008). To avoid these losses and guarantee a nutritional value and organoleptic quality comparable to fresh egg products, freeze-drying (FD) is a good alternative drying treatment (PIGNOLI et al., 2009). The FD method consists of freezing the sample at low temperature (about $-50{ }^{\circ} \mathrm{C}$ ) and applying a vacuum (about $40 \mu \mathrm{mHg}$ ). The water content in egg samples passes from the solid to the vapor phase while leaving the other components unchanged (DALGLEISH, 1990). Thus, this process allows the production of dried eggs that are nutritive and attractive to consumers. Hence, the aim of this work was to verify differences between Brazilian desserts with FD, SD and fresh egg products using physicochemical and sensory analysis. The obtained data from the sensory analyses were studied further through the employment of principal component analysis (PCA) to identify possible similarities between the sensory attributes of different samples (MATOS et al., 2003).

\section{Materials and methods}

\subsection{Freeze-dried egg samples}

Fresh eggs were purchased from Universidade Estadual de Maringá Experimental Farm, located in the Paraná State, Brazil. The eggs were washed with water and alkaline detergent, dried at room temperature and cracked. Half the samples were used to

\footnotetext{
Received 27/3/2013

Accepted 27/6/2013 (006056)

${ }^{1}$ Federal University of Technology Parana State - UTFPR, Campo Mourão, PR, Brazil

2 Department of Chemistry, State University of Maringa - UEM, Av. Colombo, 5790, CEP 87020-900, Maringa, PR, Brazil, e-mail: mmakoto@uem.br

${ }^{3}$ Food Technology Department, Federal University of Technology Parana State - UTFPR, Londrina, PR, Brazil

${ }^{*}$ Corresponding author
} 
produce $\mathrm{WE}$, while the other half were separated into EW and EY. The samples were homogenized in a blender for 30 seconds and placed in sterilized bottles. The samples of WE and EY were pasteurized for 3.5 minutes at $60^{\circ} \mathrm{C}$, and the $\mathrm{EW}$ at $56.7^{\circ} \mathrm{C}$ for 2 minutes in a water bath. After that, the samples were subjected to thermal shock at $0{ }^{\circ} \mathrm{C}$, placed in sterilized metal receivers, frozen at $-40{ }^{\circ} \mathrm{C}$ for at least 24 hours and freeze-dried at about $-52{ }^{\circ} \mathrm{C}$ and $40 \mu \mathrm{mHg}$ (LIOBRAS, LIOTOP 101, São Carlos city, São Paulo State, Brazil). The dried samples were triturated, packed in plastic bags and stored at room temperature.

The studied SD egg products (WE, EY and EW) were kindly provided by NaturOvos, Salvador do Sul city, Rio Grande do Sul State, Southern Brazil.

\subsection{Confection formulations and preparation}

The chosen desserts were: condensed milk pudding $(\mathrm{P})$, quindim $(\mathrm{Q})$ and meringue $(\mathrm{M})$, each with only one type of egg product powder. The employed formulations are described in Table 1.

\section{Condensed milk pudding $(P)$}

The P samples made with FD and SD whole egg were prepared by mixing WE powder with water and slowly stirring in a plastic container (NATUROVOS, 2012), while P samples made with fresh (F) whole eggs followed the same formulation without addition of water. The mixture was placed in a blender at speed 1 until a homogeneous mass was obtained, transferred to a metal container greased with caramel and double-boiled in a household oven at approximately $200^{\circ} \mathrm{C}$ for 1 hour. After this time, $\mathrm{P}$ samples were cooled to room temperature, placed in a plastic form, labeled and kept in a refrigerator at $2-8^{\circ} \mathrm{C}$ until the sensory analysis, which was held on the same day. Every P sample was divided into fifty small pieces of approximately the same size so as not to influence the sensory evaluations.

\section{Quindim (Q)}

The three Q mixtures followed the same steps as P's confection, but in this case EY powder was used (NATUROVOS, 2012). They were divided in twelve portions and placed in

Table 1. Ingredient composition (\%) of prepared desserts ${ }^{\mathrm{a}}$.

\begin{tabular}{llc}
\hline \multicolumn{1}{c}{ Sample } & \multicolumn{1}{c}{ Ingredients } & Quantity $(\%)$ \\
\hline \multirow{4}{*}{ Condensed milk pudding } & WE powder & 3.60 \\
& Water & 10.70 \\
& Fresh milk & 51.40 \\
& Condensed milk & 34.30 \\
\hline \multirow{5}{*}{ Quindim } & EY powder & 17.70 \\
& Water & 21.80 \\
& Fresh coconut & 16.30 \\
\multirow{3}{*}{ Meringue } & Refined sugar & 44.20 \\
& EW powder & 4.33 \\
& Water & 29.00 \\
\hline
\end{tabular}

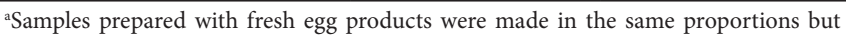
without addition of water. metallic forms $(70 \times 30 \mathrm{~mm})$ greased with butter and refined sugar. The forms were then placed in a larger aluminum form $(38 \times 27 \mathrm{~cm})$ with water and double-boiled in a household oven at approximately $180^{\circ} \mathrm{C}$ for 40 minutes. The obtained Q samples were placed in paper forms, labeled and kept in a refrigerator at $2-8^{\circ} \mathrm{C}$ until the sensory analysis (held on the same day). Every Q sample was divided into eight smaller pieces with approximately the same size.

\section{Meringue (M)}

The confection of three samples of $\mathrm{M}$ using the three kinds of EW followed the recipe of NaturOvos (2012). The mass made with FD or SD powder was gently mixed with filtered potable water and heated to the boiling point. Afterwards, it was placed in a blend mixer and refined sugar was added in small quantities until the 'snow point.' The forms $(38 \times 27 \mathrm{~cm})$ were greased with butter and sugar. The mass was divided in small portions of approximately the same size, and kept at room temperature until the sensory analysis.

\subsection{Proximate composition analyses}

The moisture, ash and protein contents were determined according to Cunnif (ASSOCIATION..., 2010). Analytical grade reagents were used and chemical analyses were performed in triplicate. To calculate the protein content, the obtained values were multiplied by a specific factor (6.25).

\subsection{Color analysis}

The powdered samples (WE, EY and EW) of freeze- and spray-dried eggs had their color analyzed. About $10 \mathrm{~g}$ of each sample were placed in 3 Petri dished $(100 \times 12 \mathrm{~mm})$. The Hunter Lab colorimeter (MiniScan EZ) was used to determine egg color. Readings were taken in triplicate.

\subsection{Sensory analyses}

All the developed formulations (condensed milk pudding $(\mathrm{P})$, quindim $(\mathrm{Q})$ and meringue $(\mathrm{M})$ ) had their sensory characteristics evaluated by color, smell, flavor, texture, and overall acceptability (DUTCOSKY, 2007; MEILGAARD; CIVILLE; CARR, 1999; SEDOSKI et al., 2012; KHOURYIEH; ARAMOUNI, 2012). A minimum of 50 untrained panelists were informed about the aim of the study and asked about their gender, age and occupation. The sensory analysis was distributed between three different days, with one type of sample (with WE, EY or EW) evaluated each day. Each panelist evaluated three samples in three different containers coded with a random three digit number, and rated each on a nine-point hedonic scale $(9=$ like extremely; $5=$ neither like nor dislike; $1=$ dislike extremely). All samples were divided into small portions with approximately the same dimensions. The sensory analysis project was approved by the Universidade Estadual de Maringá Research Ethics Committee, process number 98798, in accordance with 196/96 resolution of Brazilian health council (BRASIL, 1996). 


\subsection{Statistical analysis}

The statistical evaluation of the data was carried out with analysis of variance and Tukey's test $(\mathrm{p}<0.05)$ using the SAS (STATISTICAL...,1992) program. The data from the sensory analyses were also treated by principal component analysis (PCA) employing the MATLAB program (The MathWorks, Natick, USA).

\section{Results and discussion}

\subsection{Proximate composition}

The values for moisture, ash and protein content obtained from the FD egg samples are shown in Table 2.

All the obtained results for moisture and ash content of freeze-dried egg samples were in agreement with the Brazilian standard (UNIVERSIDADE..., 2001). Moisture can influence some important properties of egg products but that fact was not observed in this work (RAO; LABUZA, 2012). The relative protein contents of the dried samples were $\mathrm{EW}>\mathrm{WE}>\mathrm{EY}$, as expected EW showed the highest values $(81.00 \pm 1.18 \%)$ (MINE, $1995)$ because the composition of EW is basically protein and minerals, while EY $(31.19 \pm 2.44)$ showed representative quantities of lipids (32-35\%) and others components (KOVACSNOLAN; PHILLIPS; MINE, 2005).

\subsection{Color analysis}

Color is an important attribute of foods because it can increase or decrease its acceptability by panelists (GOLDBERG et al., 2012). The color intensity of egg products directly correlates with the color intensity of confections made with them. The FD egg samples showed more intense color

Table 2. Moisture, ash and protein obtained for WE, EY and EW freeze-dried samples ${ }^{\mathrm{a}}$.

\begin{tabular}{cccc}
\hline Sample & Moisture (\%) & Ash (\%) & Protein (\%) \\
\hline WE & $6.07 \pm 0.13$ & $3.29 \pm 0.11$ & $48.75 \pm 0.31$ \\
EY & $3.75 \pm 0.16$ & $3.45 \pm 1.14$ & $31.19 \pm 2.44$ \\
EW & $8.03 \pm 1.52$ & $4.55 \pm 0.15$ & $81.00 \pm 1.18$ \\
\hline
\end{tabular}

${ }^{a}$ Values represent the means of triplicate sample analysis results with respective standard deviations.

Table 3. Color analysis of freeze- and spray-dried egg products (WE, YE and EW) ${ }^{\mathrm{a}}$.

\begin{tabular}{cccc}
\hline Sample & $L^{b}$ & $A^{c}$ & $b^{d}$ \\
\hline WE-FD & $72.64 \pm 1.17$ & $13.22 \pm 0.37$ & $41.82 \pm 0.34$ \\
WE-SD & $86.45 \pm 0.48$ & $6.42 \pm 0.09$ & $29.13 \pm 0.17$ \\
EY-FD & $80.16 \pm 0.46$ & $8.48 \pm 0.22$ & $45.03 \pm 0.28$ \\
EY-SD & $88.25 \pm 0.14$ & $5.41 \pm 0.07$ & $33.18 \pm 0$. \\
EW-FD & $88.80 \pm 0.98$ & $1.31 \pm 0.29$ & $30.67 \pm 1.42$ \\
EW-SD & $96.60 \pm 0.45$ & $-0.58 \pm 0.8$ & $18.69 \pm 0.19$ \\
\hline
\end{tabular}

${ }^{a}$ Data are expressed as means \pm standard deviation; ${ }^{b} L$ represents the lightness of the sample, where $100=$ white and $0=$ black; ${ }^{c} A$ designated redness when the values are positive and greenness when the values are negative; ${ }^{d} b$ designated yellowness when the values are positive and blueness when the values are negative. attributes in relation to SD samples. The color analysis results are shown in Table 3.

In all cases, the SD samples had more lightness $\left(L^{*}\right)$ than the FD samples. This corroborates the fact that the FD samples had more intense color than the others. The $a^{*}$ and $b^{*}$ grades for FD samples were higher than obtained for SD samples, which confirms the superior intensity of the color attribute.

These results denote the retention of egg nutrients after the freeze-drying process in the samples and/or a slower loss of those nutrients in comparison with the SD drying method. Egg color correlates mainly with the content of oxycarotenoids; their concentrations are linked to intensity of color, hence their quantities are higher in FD samples (KARUNAJEEWA et al., 1984).

Although the responses for the color attribute showed no significant differences $(\mathrm{P}<0.05)$, the color values for $\mathrm{FD}$ egg samples were $10 \%$ higher than those obtained for SD samples.

\subsection{Sensory analyses}

The sensory analysis was divided into three distinct days, with one day for each kind of confection (P, Q and $M)$. The untrained panelists $(n=50$, age $>18$ years) were recruited from students, professors and technicians at the Universidade Tecnológica Federal do Paraná, Campo Mourão, Paraná State, Brazil. They were instructed about the study and possible risks, as well as requested to look at and smell the confection sample before tasting and assigning a score to it. The objective of the sensory analysis was to evaluate if panelists liked or disliked the desserts prepared with FD egg products in comparison with SD and fresh egg products. The results are presented in Table 4.

This paragraph will focus on the data obtained for $\mathrm{P}$ samples, because they showed very interesting results. For smell, $P$ presented a significant difference between fresh and FD samples, but not between FD and SD samples. That result was expected, because the drying treatments remove the water from egg, the remaining components are concentrated, including the aroma components, thus increasing the strength of its smell and flavor. This fact can influence the panelists' responses about these sensory factors, as observed. For flavor, the P samples showed significant differences between the three formulations; however the values obtained for that attribute were satisfying. The texture values were statistically different between $P$ samples prepared with FD and SD-WE, but no difference was detected in relation to other samples.

The data presented in Table 4, after analysis of variance with subsequent comparison by Tukey's test $(\mathrm{P}<0.05)$, showed that the confections prepared with FD egg products had good acceptance by panelists.

The color attribute showed no significant differences for every sample, which corroborates the fact that comfits prepared with freeze-dried egg products have been accepted just like their fresh and SD counterparts.

The data obtained in the sensory analyses were treated by principal component analysis (PCA) to better understand the 
acceptability of FD products by panelists and compare them with other formulations.

PCA can be used to reduce the number of original variables to a few reduced variables or Principal Components (PCs) by keeping only the largest or most significant PCs. PCA decomposes an $\mathbf{X}$ matrix into two smaller matrices, one of scores (T) and the other of loadings (P) as follows (BRERETON, 2000) (Equation 1):

$\mathrm{X}=\mathrm{T} \cdot \mathrm{P}^{\mathrm{T}}$

Each PC is characterized by a scores vector, a loadings vector and an eigenvalue. The sum of eigenvalues over all significant components should be approximately equal to the sum of squares of the original data. The first PC can be defined as the best-fit straight line in the multi-dimensional space. The scores represent the distance along this line, and the loadings the direction (angle) of the straight line. Another important property of the PCs is often called orthogonality (BRERETON, 2000). For three desserts, as in the case of this study, ideally three PCs are calculated to create a three-dimensional subspace of the original multidimensional space. The results of the PCA are illustrated in Figure 1.

Three groups were obtained whose integrants have analogous characteristics: Group 1: EY-F, WE-F, WE-FD and WE-SD; Group 2: EW-F, EW-FD and EW-SD; Group 3: EYFD and EY-SD. These results indicate that confections made with FD egg products have acceptance equal to those made with SD egg products. The confections prepared with group 1 integrants showed similar characteristics and were separated by the parameters color, smell and overall acceptability. However, the same foods had good acceptance when prepared with FD

Table 4. Sensory analysis of confectionery (P, Q and M) made with egg products obtained by three different treatments . $^{\mathrm{a}}$

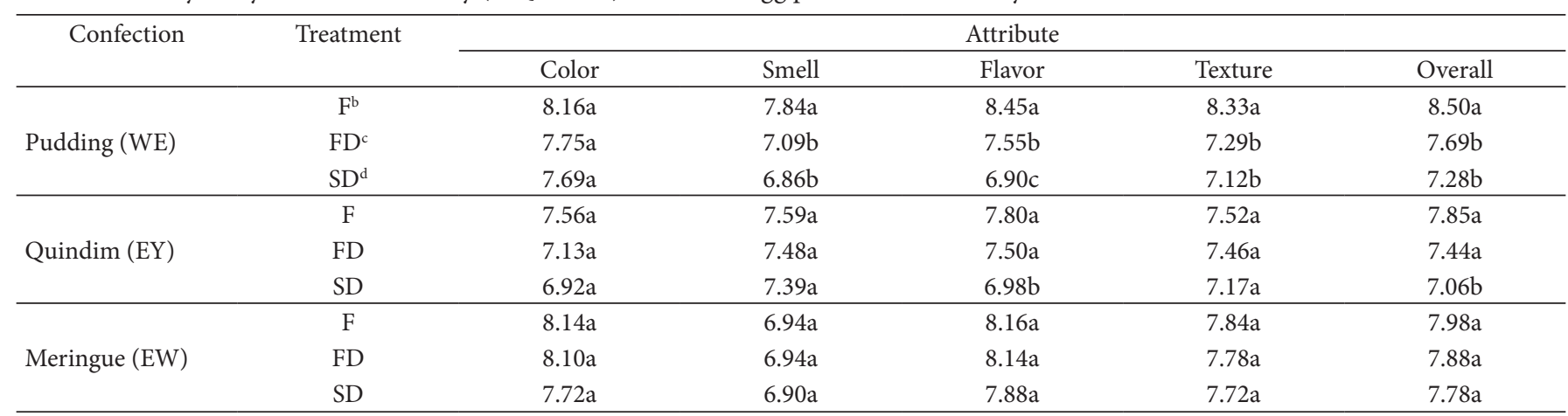

${ }^{a}$ Means followed by the same letter in the column are not significantly different by Tukey's test; ${ }^{b} \mathrm{~F}=$ fresh; ${ }^{\mathrm{c}} \mathrm{FD}=$ freeze-dried; ${ }^{\mathrm{d} S D}=$ spray-dried.

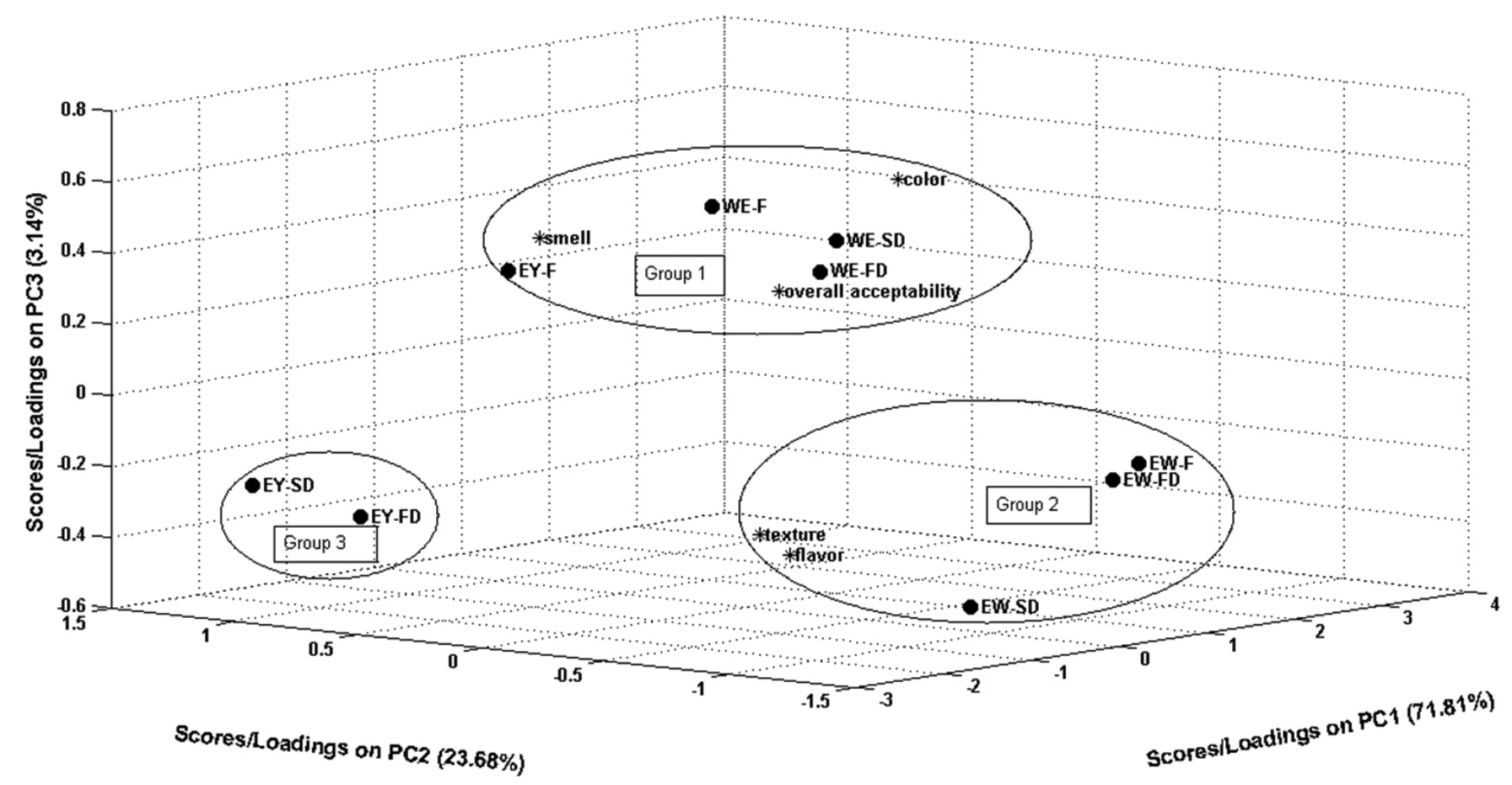

Figure 1.3D graphic of scores and loadings for PCA on sensory analysis of P(WE), Q(EY) and M(EW) fresh, freeze- and spray-dried egg products. 
and SD egg samples. In fact, the drying process affected those attributes but did not compromise its acceptability. Group 2 is composed of 3 formulations of $\mathrm{M}$ with 3 kinds of $\mathrm{EW}$ and was distinguished by the attributes flavor and texture. This indicates that the panelists did not detect any differences between formulations, especially in these attributes. In any case, the results showed that FD egg products can be used to prepare foods and substitute for fresh eggs with good acceptance and maintenance of the products' sensory characteristics.

\section{Conclusions}

PCA on the results obtained from sensory analyses, along with the physicochemical data, showed that Brazilian confections made with FD egg products can combine good acceptance and all the advantages of the freeze-drying method. The production of FD egg products on an industrial scale can provide consumers with foods with healthier and better nutritional values than those obtained using SD.

\section{Acknowledgments}

The authors would like to thanks the NaturOvos for SD egg samples kindly donated for use in this study.

\section{References}

AMERICAN EGG BOARD - AEB. Nutrient composition. Illinois, 2012. Disponível em: <http://www.aeb.org/food-manufacturers/ egg-nutrition-and-trends/nutrient-composition\#1>. Acesso em: 29 out. 2012 .

ASSOCIATION OF OFFICIAL ANALYTICAL CHEMISTS - AOAC. Official methods of analysis. 18th ed. Washington: Association of Official Analytical Chemists, 2010.

AYADI, M. A. et al. Effect of moderate spray drying conditions on functionality of dried egg white and whole egg. Journal of Food Science, v. 73, n. 6, p. 281-287, 2008. PMid:18782229. http://dx.doi. org/10.1111/j.1750-3841.2008.00811.x

BRASIL. Resolução no 196, de 10 de outubro de 1996. Aprova as diretrizes e normas regulamentadoras envolvendo seres humanos. Diário Oficial da República Federativa do Brasil, Brasília, DF, 1996. Disponível em: <http://conselho.saude.gov.br/ resolucoes/1996/Reso196.doc>. Acesso em: 29 out. 2012.

BRERETON, R. G. Introduction to multivariate calibration in analytical chemistry. Analyst, v. 125, p. 2125-2154, 2000. http://dx.doi. org/10.1039/b003805i

CABONI, M. F. et al. Effect of processing and storage on the chemical quality makers of spray-dried whole egg. Food Chemistry, v. 92, n. 2, p. 293-303, 2005. http://dx.doi.org/10.1016/j.foodchem.2004.07.025

COIMBRA, J. S. R. et al. Density, heat capacity and thermal conductivity of liquid egg products. Journal of Food Engineering, v. 74, p. 186190, 2006. http://dx.doi.org/10.1016/j.jfoodeng.2005.01.043

DALGLEISH, J. M. Freeze-drying for the food industries. New York: Elsevier, 1990.

DUTCOSKY, S. D. Análise sensorial de alimentos. 2. ed. Curitiba: Ed. da Pontifícia Universidade Católica do Paraná, 2007.

GALOBART, J. et al. Lipid oxidation in fresh and spray-dried eggs enriched with w3 and w6 polyunsaturated fatty acids during storage as affected by dietary vitamin $\mathrm{E}$ and canthaxanthin supplementation. Poultry Science, v. 80, p. 327-337, 2001.
GOLDBERG, E. M. et al. Fatty acid profile and sensory characteristics of table eggs from laying hens fed hempseed and hempseed oil. Journal of Food Science, v. 78, n. 4, p. 153-160, 2012. PMid:22429187. http:// dx.doi.org/10.1111/j.1750-3841.2012.02626.x

GUILMINEAU, F.; KULOZIK, U. Influence of a thermal treatment on the functionality of hen's egg yolk in mayonnaise. Journal of Food Engineering, v. 78, p. 648-654, 2007. http://dx.doi.org/10.1016/j. jfoodeng.2005.11.002

JAEKEL, T.; DAUTEL, K.; TERNES, W. Preserving functional properties of hen's egg yolk during freeze-drying. Journal of Food Engineering, v. 87, p. 522-526, 2008. http://dx.doi.org/10.1016/j. jfoodeng.2008.01.006

JONES, D. R. Egg functionality and quality during long-term storage. International Journal of Poultry Science, v. 6, n. 3, p. 157-162, 2007. http://dx.doi.org/10.3923/ijps.2007.157.162

KARUNAJEEWA, H. et al. Review of factors influencing pigmentation of egg yolks. World's Poultry Science Journal, v. 40, p. 52-65, 1984. http://dx.doi.org/10.1079/WPS19840006

KHOURYIEH, H.; ARAMOUNI, F. Physical and sensory characteristics of cookies prepared with flaxseed flour. Journal of Science Food and Agriculture, v. 92, p. 2366-2372, 2012. PMid:22419245. http:// dx.doi.org/10.1002/jsfa.5642

KING, A. J. Multidisciplinary uses of chicken egg. Avian Biology Research, v. 2, n. 3, p. 107-119, 2009. http://dx.doi. org/10.3184/175815508X402455

KOÇ, M. et al. Functional and physicochemical properties of whole egg powder: effect of spray drying conditions. Journal of Food Science and Technology, v. 48, n. 2, p. 141-149, 2011a. PMid:23572728 PMCid:PMC3551060. http://dx.doi.org/10.1007/s13197-0100159-1

KOÇ, M. et al. Physicochemical characterization of whole egg powder microencapsulated by spray drying. Drying Technology, v. 29, n. 7, p. 780-788, 2011b. http://dx.doi.org/10.1080/07373937.2010.538820

KOVACS-NOLAN, J.; PHILLIPS, M.; MINE, Y. Advances in the value of eggs and egg components for human health. Journal of Agricultural and Food Chemistry, v. 53, p. 8421-8431, 2005.

MANN, K. et al. Identification of new chicken egg proteins by mass spectrometry-based proteomic analysis. World's Poultry Science Journal, v. 64, n. 2, p. 209-218, 2008.

MATOS, G. D. et al. Análise exploratória em Química Analítica com emprego de quimiometria: PCA e PCA de imagens. Analytica, v. 6, p. 38-50, 2003.

MEILGAARD, M.; CIVILLE, G. V.; CARR, B. T. Sensory evaluations techniques. 3. ed. London: CRC Press Inc., 1999. http://dx.doi. org/10.1201/9781439832271

MINE, Y. Recent advances in the understanding of egg white protein functionality. Trends in Food Science and Technology, v. 6, n. 7, p. 225-232, 1995. http://dx.doi.org/10.1016/S0924-2244(00)89083-4

NATUROVOS. Livro de Receitas. Disponível em: <http://www. naturovos.com.br/site/_resources/_upload/_receita/livro receitas Naturovos.pdf $>$. Acesso em: 11 mar. 2012.

PIGNOLI, G. et al. Effects of different rearing and feeding systems on lipid oxidation and antioxidant capacity of freeze-dried egg yolks. Journal of Agriculture and Food Chemistry, v. 57, p. 1151711527, 2009.

POWRIE, W. D.; NAKAIM, S. The chemistry of eggs and egg products. In: STADELMAN, W. J.; COTTERILL, O. J. Egg science and technology. New York: A V I Publishing Company, 1986. p. 97-139.

RAO, Q.; LABUZA, T. P. Effect of moisture content on selected physicochemical properties of two commercial hen egg white 
powders. Food Chemistry, v. 132, p. 373-384, 2012. http://dx.doi. org/10.1016/j.foodchem.2011.10.107

ROSSI, M. et al. Functional properties of pasteurised liquid egg products as affected by hygienic quality of the raw eggs. LWT - Food Science and Technology, v. 43, n. 3, p. 436-441, 2010.

SEDOSKI, H. D. et al. Sensory evaluation and quality indicators of mutritionally-enhanced egg product with w-3 rich oils. LWT - Food Science and Technology, v. 47, p. 459-464, 2012.

SILVA, F. B. et al. Composição em ácidos graxos e colesterol na gema de ovos comerciais. Pubvet, v. 2, n. 12, p. 12-22, 2008.

SIMOPOULOS, A. P. Evolutionary aspects of diet: The omega-6/ omega-3 ratio and the brain. Molecular Neurobiology, v. 44, n. 2, p. 203-215, 2011. PMid:21279554. http://dx.doi.org/10.1007/ s12035-010-8162-0

SPENCE, J. D.; JENKINS, D. J. A.; DAVINGNON, J. Dietary cholesterol and egg yolks: Not for patients at risk of vascular disease. Canadian Journal of Cardiology, v. 26, n. 9, p. 336-339, 2010. http://dx.doi. org/10.1016/S0828-282X(10)70456-6

STATISTICAL ANALISYS SYSTEM INSTITUTE - SAS. User's Guide: Statistics. Cary: SAS Institute Inc., 1992.

UNITED STATES DEPARTMENT OF AGRICULTURE - USDA. Agricultural Research Service. USDA National Nutrient Database for Standard Reference, Release 25. Washington D.C, 2012.
Disponível em: <http://www.ars.usda.gov/ba/bhnrc/nd>. Acesso em: 29 out. 2012.

UNIVERSIDADE DE SÃO PAULO - USP. Departamento de Alimentos e Nutrição Experimental. Projeto integrado de composição de alimentos. São Paulo: USP, 2001. Disponível em: $<$ http://www.fcf.usp.br/tabela/tbcamenu.php $>$. Acesso em: 23 set. 2012.

VAN DER PLANCKEN, I.; VAN LOEY, A; HENDRICKX, M. E. Effect of heat-treatment on the physico-chemical properties of egg white proteins: A kinetic study. Journal of Food Engineering, v. 75, n. 3, p. 316-326, 2006. http://dx.doi.org/10.1016/j.jfoodeng.2005.04.019

VERARDO, V. et al. Influence of storage conditions on cholesterol oxidation in dried egg pasta. Journal of Agriculture Food and Chemistry, v. 58, p. 3586-3590, 2010.

WENZEL, M.; SEUSS-BAUM, I; SCHLICH, E. Influence of pasteurization, spray- and freeze-drying, and storage on the carotenoid content in egg yolk. Journal of Agriculture Food and Chemistry, v. 58, n. 3, p. 1726-1731, 2010.

WENZEL, M.; SEUSS-BAUM, I; SCHLICH, E. Influences of storage time and temperature on the xanthophylls content of freeze-dried egg yolk. Food Chemistry,v. 124, p. 1343-1348, 2011. http://dx.doi. org/10.1016/j.foodchem.2010.07.085 